\title{
Population decline in Lithuania: who lives in declining regions and who leaves?
}

\author{
Rūta Ubarevičienè $\dot{e}^{\mathrm{a}, \mathrm{b}}$ (1) and Maarten van Hamª,c (D)
}

\begin{abstract}
Since the 1990s, Lithuania lost almost one-quarter of its population, and some regions within the country lost more than $50 \%$ of their residents. Such a sharp population decline poses major challenges to politicians, policy-makers and planners. The aim of this study is to obtain more insight into the recent processes of socio-spatial change and the role of selective migration in Lithuania. The main focus is on understanding who lives in those regions which are rapidly losing population, and who is most likely to leave these regions. This is one of the first studies to use individual-level Lithuanian census data from 2001 and 2011. We found that low socio-economic status residents and older residents dominate the population of shrinking regions, and unsurprisingly that the most 'successful' people are the most likely to leave such regions. This process of selective migration reinforces the negative downward spiral of declining regions. As a result, socio-spatial polarization is growing within the country, where people with higher socio-economic status are increasingly overrepresented in the largest city-regions, while the elderly and residents with a lower socio-economic status are overrepresented in declining rural regions. This paper provides empirical evidence of selective migration and increasing regional disparities in Lithuania. While the socio-spatial changes are obvious in Lithuania, there is no clear strategy on how to cope with extreme population decline and increasing regional inequalities within the country.
\end{abstract}

\section{ARTICLE HISTORY}

Received 22 October 2016; Accepted 23 March 2017

\section{KEYWORDS}

Population decline; shrinking regions; internal migration; socio-spatial polarization; Lithuania

JEL J11; 015; P20; R23

\section{INTRODUCTION}

In the last decades, many developed countries have been confronted with regional population decline (Haartsen \& Venhorst, 2010; Haase, Athanasopoulou, \& Rink, 2016; Hospers, 2012; Reher, 2004). There is increasing attention for the causes and consequences of these so-called

\section{CONTACT}

(Corresponding author) r.ubareviciene@tudelft.nl

${ }^{a} \mathrm{OTB}$ - Research for the Built Environment, Faculty of Architecture and the Built Environment, Delft University of Technology,

Delft, the Netherlands

'Institute of Human Geography and Demography, Lithuanian Social Research Centre, Vilnius, Lithuania

'School of Geography and Geosciences, University of St Andrews, St Andrews, UK 
'shrinking regions', which is reflected in media attention and in academic and political debates (Sousa \& Pinho, 2015). These debates largely portray declining regions as deteriorating and problematic and emphasize the need to counter the population decline.

Central and Eastern European (CEE) countries $^{1}$ are losing their populations at the national level, and at some of the highest rates in the world. Between 2000 and 2010 they lost on average $-3.7 \%$ of their population. In Lithuania, the population decline was $-10.4 \%$ (United Nations, 2015). In a quarter of a century, since the early 1990s, Lithuania lost more than one-fifth of its residents (a rapid decrease from 3.7 million in 1989 to 2.9 million in 2015), which makes it one of the countries with the greatest population decline in the world (The Economist, 2017; United Nations, 2015). Some regions lost more than $50 \%$ of their residents. Such a strong decrease in population, not seen in any Western European country, was the result of the combined effects of major political, economic and social transitions. Large-scale emigration, natural population decline and changing residential mobility patterns caused the socio-spatial landscape of Lithuania to change in a fast and dramatic way.

The pattern of population change in Lithuania shows a concentration of population in the metropolitan areas (MAs) and a sharp decline in peripheral rural regions (Ubarevičiené, van Ham, \& Burneika, 2016). It has been shown that internal migration plays a major role in the processes of population redistribution and growing spatial imbalances (Ambinakudige \& Parisi, 2015; Ubarevičiené, 2016). However, little is known about the directions of migration flows within Lithuania as well as the demographic and socio-economic composition of such flows. By knowing that migration tends to be selective by nature (Fratesi \& Percoco, 2014; Tervo, 2000), it can be expected that the population leaving declining regions in Lithuania is very selective as well. The extreme population decline in some regions of Lithuania and the growth of population in others can be expected to result in increasing regional differences. These differences might endanger the stability of society and the economy.

This paper seeks to obtain more insight into the recent processes of socio-spatial change in Lithuania, with specific attention for the role of selective migration. While the focus is on Lithuania, the results of this study will also be of value for other CEE countries, many of which experienced similar trajectories during recent decades (Gentile, Tammaru, \& van Kempen, 2012; Smith \& Timar, 2010). This paper will investigate the characteristics of those (1) who live in the rapidly declining regions and (2) those who are most likely to leave such regions. We will also investigate the effects of regional characteristics on population mobility. In this study we are focusing on those regions that experienced the sharpest population decline ( $-20 \%$ and more) during 2001-11. This study is one of the first to use individual-level Lithuanian census data from 2001 and 2011, and is also the first to explore internal migration and population change at the individual-level in Lithuania. Logistic regression models were used to investigate the differences between the residents of the rapidly declining regions ${ }^{2}$ and the rest of the country as well as to gain an understanding of the individual differences in migration behaviour among the residents of the rapidly declining regions.

\section{LITERATURE REVIEW ON POPULATION DECLINE, MIGRATION AND REGIONAL DIFFERENCES}

Population decline is dependent on political, economic and social conditions, and therefore it is a multifaceted and complex phenomenon (Haase, Bernt, Großmann, Mykhnenko, \& Rink, 2016). Although it is not a fundamental rule, once population decline in an area has started, it is difficult to reverse it (Hudson, 2015; see also Myrdal, 1957). Population decline often starts with economic decline, but then becomes part of a vicious circle, causing a downward spiral of the local economy, declining tax revenues, a decline in service provision and social infrastructure, and more and more abandoned homes and factories (Elshof, van Wissen, \&Mulder, 2014). Such 
developments make a region even less attractive to the people who are left behind and increase their probability to leave as well. At least in (neo-classical) theory, labour migration should eventually lead to a new (spatial) economic equilibrium as the cost of labour drops in shrinking areas, making these areas more attractive for employers (Sjaastad, 1962). However, according to Fratesi and Percoco (2014, p. 1651), 'a number of theoretical approaches ... have pointed out that migration may even give rise to larger regional disparities, especially in those cases in which it is not skill-neutral but skill-selective'. The latter authors argue that skilled people benefit most from migration and they are most likely to relocate, while the sending regions lose their human capital and eventually also their economic potential. Therefore, the process of migration is typically accompanied by increasing regional disparities, characterized by an increasing gap between 'winning' and 'losing' regions.

Most internal migration is a response to labour market conditions, educational opportunities, family factors or a desire to improve quality of life (Biagi, Faggian, \& McCann, 2011; Niedomysl, 2011; Nivalainen, 2004). For example, many studies show that the propensity to migrate drops as age increases. Young adults are more likely to move out from rural regions for education and employment reasons, while with age people accumulate 'commitments' making migration more complex and costly. The elderly are the least inclined to move and tend to age in place (Coulter \& Scott, 2015; Elshof et al., 2014; Tervo, 2000). The probability to move over longer distances also highly depends on socio-economic status; it is much lower for individuals with a weaker labour market position (Fratesi \& Percoco, 2014). Therefore, it can be expected that the effect of 'brain drain' eventually leads to an overrepresentation of low-educated, low-skilled and unemployed people in shrinking regions. Some studies show that ethnic minorities are less likely to move than those belonging to majority populations (Sjöberg \& Tammaru, 1999; Tammaru, van Ham, Leetmaa, Kährik, \& Kamenik, 2013), but some studies also find the opposite (Bonvalet, Carpenter, \&White, 1995; Finney \& Simpson, 2008). Moreover, housing characteristics also play a role in migration behaviour. For example, the probability to move is lower for owner-occupiers than for renters due to higher transaction costs for owners (Coulter \& Scott, 2015; Tervo, 2000).

A number of studies show that contextual factors such as regional unemployment rate and wage differences are key elements in understanding migration (Etzo, 2008). Many studies find that a high unemployment rate is associated with high out-migration (Ní Laoire, 2000; Nivalainen, 2004; Panagopoulos \& Barreira, 2012; Stockdale, 2004). However, Tervo (2000, p. 343) showed 'that higher origin unemployment rates increase out-migration, but not particularly for unemployed workers'. Other studies showed that there is no effect or even the reverse effect between these two variables (Elshof et al., 2014; Etzo, 2008). Labour market structure, degree of urbanization, population density and distance to major MAs are also among commonly reported contextual variables influencing migration (Nivalainen, 2004). The general trend is that people move from less to more urbanized areas, and from agricultural to industrial and service-leaded regions. However, the urban life-cycle theory says that urbanization is often accompanied by suburbanization and counterurbanization (van den Berg, Drewett, Klaassen, Rossi, \& Vijverberg, 1982), because different locations are attractive to people with different individual characteristics, needs, opportunities and motives (Ambinakudige \& Parisi, 2015). Meanwhile, immobility can be an outcome of constrains or a product of someone's choice (Coulter \& Scott, 2015).

According to Fratesi and Percoco (2014), persistent population decline, especially when it accompanies an ageing population and brain drain, is the most harmful and difficult to reverse, and leads to imbalances between regions, and may hinder economic growth. On the other hand, although Stockdale (2004) identifies rural out-migration as a 'loss of human and social capital', she emphasizes the positive side of migration as mobile individuals can enjoy opportunities that would otherwise not be available to them. Moreover, rural shrinkage is a natural response to structural changes in the economy, including increasing efficiency of the agricultural sector. Sousa and Pinho (2015) argue that shrinkage could be perceived as an opportunity for planners 
and decision-makers, but new and innovative solutions must be designed to manage structural shrinkage processes.

\section{POPULATION DISTRIBUTION IN LITHUANIA: SHIFT FROM SOCIALIST TO POST-SOCIALIST PERIOD}

For five decades ${ }^{3}$ Lithuania and other CEE countries were under the communist regime and subject to a command economy model, which was based on the principles of central planning (Borén \& Gentile, 2007; Sjöberg, 1999). During this period, population movement was regulated between the communist states and even within national borders. An even spread of population was the aim of the communist planning doctrine, and it was intended to achieve that through the spatial distribution of human and economic resources (Bertaud \& Renaud, 1997). In many $\mathrm{CEE}$ countries there was an intention to develop a uniform network of regional centres, while suppressing the growth of a few major cities. In the Baltic States, which had a major role as suppliers of agricultural production to the Soviet Union, residents were encouraged to live and work in rural settlements where they were provided with housing facilities and income, often at a higher standard than in the cities (Tammaru, 2001). By the end of the Soviet period, one-third of the population of the Baltic States resided in rural settlements and had jobs in the primary sector. In Lithuania, there was a strategy to decentralize population and industry into medium and small-size cities (Vanagas, Krišjane, Noorkoiv, \& Staniūnas, 2002). Such territorial organization was only possible in a society without market competition and private property (all property was nationalized in the Soviet Union).

It is not surprising that the sudden change in the political and economic situation in the 1990s resulted in a new stage of regional development as well as socio-spatial change in Lithuania. The inherited Soviet urban system did not meet the needs of the post-socialist society. The extreme population decline, and the growing regional disparities in Lithuania of the last decades, can be largely considered as the outcome of Soviet planning principles. For decades regional disparities were prevented by strict planning policies. Many regions, whose growth had been stimulated during the Soviet period by providing jobs in low-tech industry, suddenly became unable to provide a sufficient level of employment and standard of living under a market led neo-liberal economic system. Previously controlled flows of internal migration changed direction, and many people moved towards the larger cities. Moreover, economic downturn and a sharp rise in unemployment, combined with accession to the European Union, stimulated emigration (Anniste, Tammaru, Pungas, \& Paas, 2012; Black, Engbersen, Okólski, \& Pantîru, 2010; Thaut, 2009).

Emigration accounts for around $80 \%$ of the population decline in Lithuania over the past decade, and Lithuania now has one of the highest emigration rates in the European Union (EUROSTAT, 2016; Statistics Lithuania, 2012). At the same time, birth rates dropped sharply, which happened so suddenly that some demographers have called it the 'demographic shock' (Eberstadt, 1994; Rychtaříková, 1999; Sobotka, Zeman, \& Kantorová, 2003; Steinführer \& Haase, 2007). In Lithuania, since 1994 the crude rate of natural population change has been negative and decreasing; between 2001 and 2016 the average annual rate was -3.6 per 1000 people. It means that due to the natural change, population dropped by 185,000 over this period, which accounts for $6 \%$ of the total country's population (Statistics Lithuania, 2017). The total population decline unevenly affected regions within Lithuania and as a result regional differences increased. At the same time income inequality also increased as not all groups benefitted equally from the new market economic system (Kährik \& Tammaru, 2008; Valatka, Burneika, \& Ubarevičienè, 2016).

Despite the general population decline in Lithuania, an increasing concentration of population is observed in the major city-regions, albeit the population is dropping in the inner cities themselves (Ubarevičiene et al., 2016). This is a spatial pattern common for all CEE countries, where urban expansion of the major cities is taking place due to the intense suburban development 
since the early 1990s (Kok \& Kovács, 1999; Leetmaa \& Tammaru, 2007; Nuissl \& Rink, 2005; Ouředníček, 2007). According to Ehrlich, Kriszan, \& Lang (2012), the city-regions can be called the 'winners' of the socio-spatial changes, while other areas of CEE countries experience adverse developments. The most radical demographic changes take place in the peripheral countryside regions, which are losing population at the highest rates and experience profound changes in the demographic and socio-economic composition (Pociūtè-Sereikienè, Kriaučiūnas, and Ubarevičienè, 2014). These regions are characterized by low population density, dominance of employment in agriculture and relatively large distances from bigger cities (outer and inner peripheries of the countries). A significant drop in the importance of agriculture, which was prioritized under the communist regime (Enyedi, 1998; Leetmaa \& Tammaru, 2007; Tammaru, 2001), reduced the number of jobs in rural regions several times and raised the level of unemployment. Since the collapse of the Soviet Union most of the peripheral regions of Lithuania did not receive any major investments, and public as well as private service provision was constantly declining in these regions. It is evident that such a situation had to lead to out-migration, further deteriorating the living conditions for the majority of remaining population, because of the reduced likelihood of further investments in service provision or employment. Although all the factors (natural population change, internal and outward migration) contribute to the population drop and changing population composition, it has been shown that internal migration is the most effective in redistributing population from rural to urban areas (Ambinakudige \& Parisi, 2015; Ubarevičienè, 2016).

The aim of this paper is to obtain more insight into the composition of the population in the rapidly declining regions in Lithuania and the composition of the flows out of these regions, as well as to understand to what extent the Soviet-made settlement system contributed to extreme population decline and population redistribution in Lithuania.

\section{DATA AND METHODS}

This is one of the first studies in Lithuania to use individual-level geocoded data from the 2001 and 2011 Lithuanian censuses. It is also the first study to explore internal migration and population change using individual data from Lithuania, so there is little prior knowledge of the underlying processes in Lithuania. Previous studies have used aggregated-level data on municipality (LAU-1) or ward (LAU-2) level, and these studies could only investigate net migration. Using individual-level data we are now able to investigate the directions and population structure of migration flows as well as the relationships between the individual characteristics which are affecting migration.

Census data, despite the advantage that they include the whole population, typically have some shortcomings when investigating migration. First, Lithuanian census data only capture a change of residence in the one-year period before the census date. It records the current place of residence and the previous place of residence if the person has moved inside Lithuania, but the exact timing of migration cannot be observed. Second, information on individual characteristics is only available on the census date. This implies that for movers we only know their characteristics after the move, but not before. So the effects of time-varying variables such as education, occupation and household status should be interpreted with caution. Third, census data in Lithuania do not provide information on intra-urban or intra-rural migration; only those moves when the boundary of the city municipality or ward (LAU-2 region) was crossed have been recorded. Fourth, census data do not contain any information on the reasons or motives of internal migration. In addition, both the Lithuanian censuses (2001 and 2011) were conducted in post-crisis periods, which could temporarily affect the directions of internal migrations. Generally, all migration studies using census data suffer from similar problems, also in other countries (Leetmaa \& Tammaru, 2007; Nivalainen, 2004; Sjöberg \& Tammaru, 1999; Tervo, 2000), but it is important to be aware 
of them when discussing study results. Despite these shortcomings in the data, this study is an important step forward in better understanding internal migration and depopulation processes in the post-socialist countries.

The focus of this research is on the most declining regions in Lithuania, where the population dropped by more than $20 \%$ between 2001 and 2011. Some urban areas of the major cities also lost a significant share of their population (partly due to suburbanization), but these were not included in this study due to the different processes underlying rural and urban decline. This study focuses on the effects of internal migration on declining regions, although also natural change and international migration are affecting population change. But these latter processes are beyond the scope of this research.

The empirical analysis is organized into three stages. First, using the aggregated-level data we investigate the compositional differences of Lithuanian population, focusing on the residents of the declining regions and those who have moved out from them. Second, we use individual-level data and run a set of binary logistic regression models to explore further the differences between the residents of the rapidly declining regions and the rest of the country. And third, we analyse the migration behaviour of individuals. Typically, a moving decision is made by households and not by individuals. Therefore, only household reference persons older than 18 years are included in the analyses ${ }^{4}$. Although the reference person is not necessarily the one who determines the decision of the whole household to move, data limitations do not allow us to include other household members into the analysis. There were $1,263,937$ (or $42 \%$ of the total population) reference persons in all the households in Lithuania in 2011. Our analysis is focused into 139,578 individuals of the rapidly declining regions, of whom 1605 have moved out of these regions between 2010 and 2011. We used multinomial logistic regression to predict probabilities of the different possible outcomes of migration behaviour and migration directions; we compared persons who did not move from the rapidly declining regions with those who moved into 'losing' and 'winning' regions. Summary statistics of the main variables included in the models can be found in Table 1 . When reporting the results we do not provide significance levels because we have full population data.

In addition to the census data, we also report some results from a survey among residents $(N=602)$ of the sparsely populated regions in Lithuania. The survey was completed in 2012 and was part of the project 'Lithuanian Sparsely Populated Areas and their Inhabitants' (SIN-02/2012). Sparsely populated areas almost fully coincide with rapidly declining regions, which are the focus of this paper.

\section{RESULTS}

\section{The declining regions of Lithuania}

Figure 1 shows the spatial pattern of population change in Lithuania. Population decline can be seen almost everywhere in the country, except in the suburban areas around the major cities. The regions with the sharpest decline in population ( $-20 \%$ and more) covered $44 \%$ of the countries' territory and inhabited around 330,000 or $11 \%$ of the total population in 2011 (urban areas of the major cities excluded). These regions with the largest population decline are mostly rural regions, but also include some smaller cities. The average size of the population and the population density of the declining regions have changed dramatically during the inter-census period (2001-11). The average regional population size in 2011 was 1700 people with a population density of 31 persons $/ \mathrm{km}^{2}$. Only 10 years earlier, in 2001, the same regions inhabited on average 2270 people with a population density of 41 persons $/ \mathrm{km}^{2}$. In total these regions have lost more than 100,000 inhabitants, or $24.5 \%$ of their population. The population of Lithuania increasingly concentrates in the major MAs, ${ }^{5}$ although the total population of these areas also dropped by $6.2 \%$ between 2001 and 2011. Despite that, these MAs are the only macro-regional centres that still have potential 


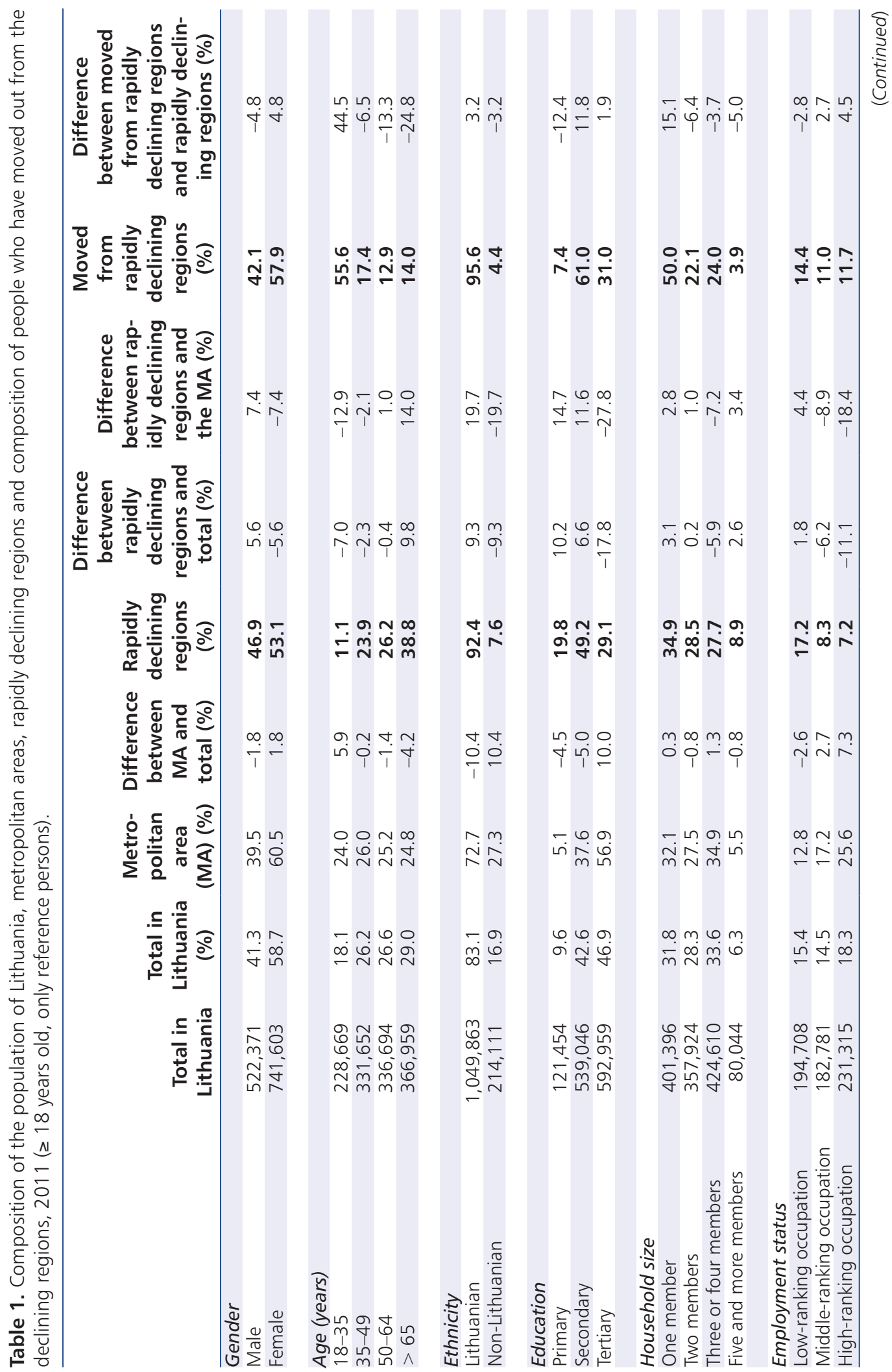




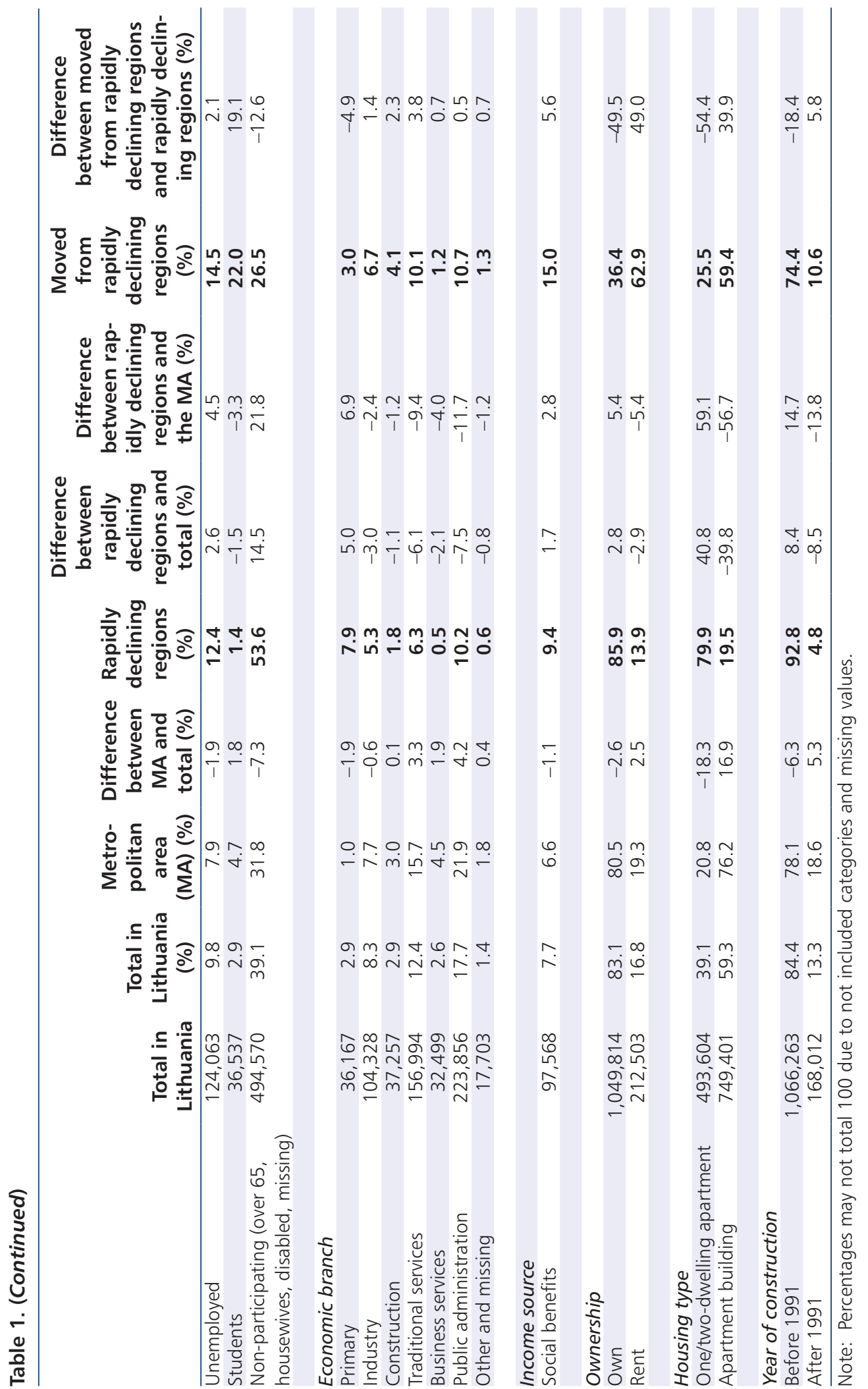




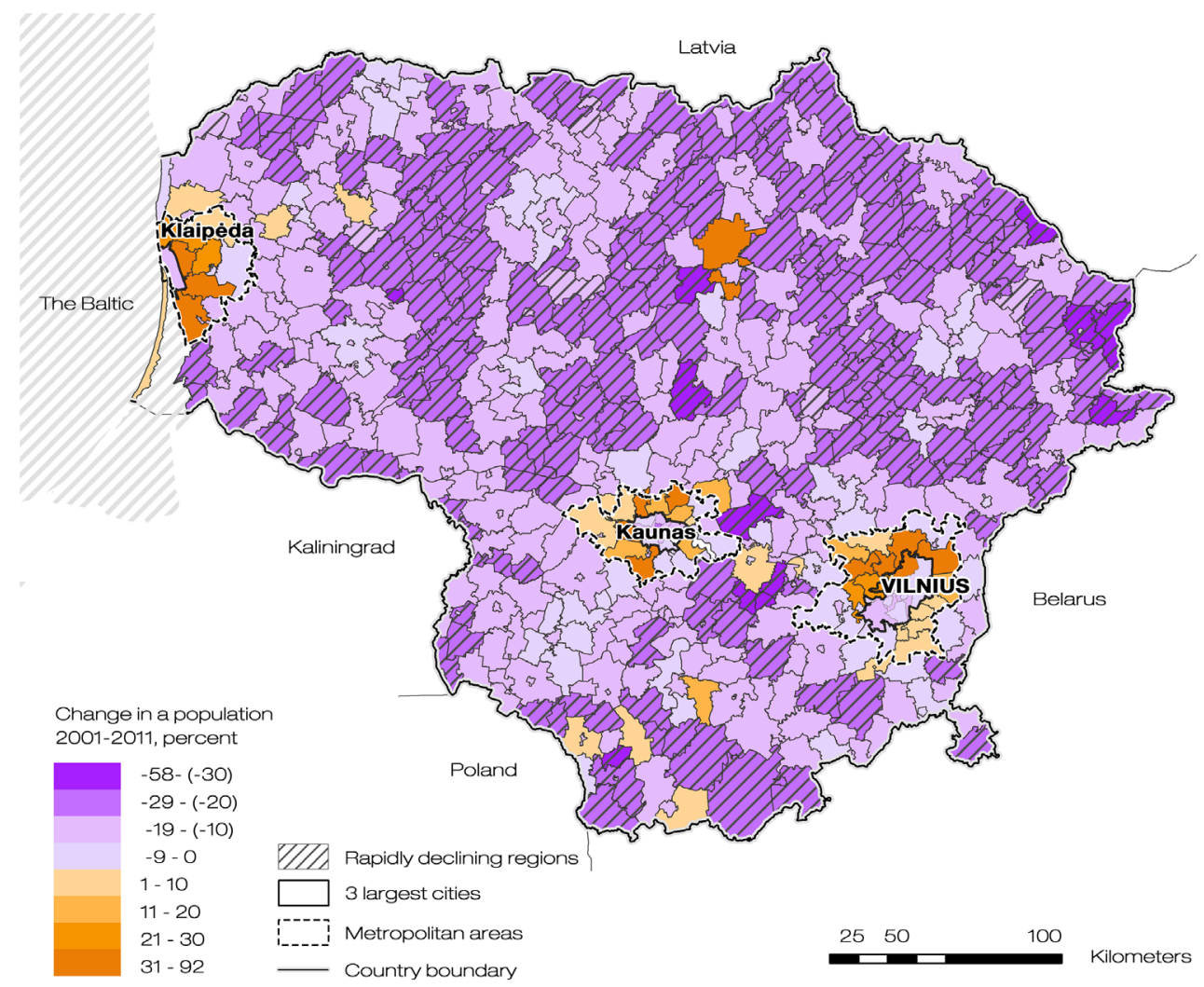

Figure 1. Population change in Lithuania, 2001-11. Source: Authors' own calculations based on the 2001 and 2011 Lithuanian censuses.

to grow in the rapidly shrinking country. Apart from population decline, an important feature of declining areas is ageing of the population. The average age of the Lithuanian population increased from 37.7 to 41.5 years in a 10 -year period, and the average age of the population in rapidly declining regions was 43.8 years in 2011 .

Table 1 contains aggregated-level data and shows compositional differences between four groups of people living in Lithuania in 2011: all Lithuanians, residents of the MAs, residents of the rapidly declining regions and people who have moved out from the declining regions. The results show that compared with the national average, residents of the declining regions were older, less educated, less skilled, there were more unemployed persons and more people who received social benefits, more people working in the primary sector and fewer in services and public administration; also more residents of the rapidly declining regions owned their home and lived in single-family houses, mainly built before 1991. These differences are more pronounced when the declining regions are compared with the MAs.

Table 1 also shows that those who moved out form the declining regions were younger, better educated and more qualified than the average of rapidly declining regions. This suggests that the most 'successful' people are leaving declining regions, which increases the socio-demographic and economic gap between the rapidly declining regions and the rest of the country. In order to obtain more insight into the underlying processes, we compared the results of the 2001 and 2011 censuses. We found that in MAs the average age of the population has dropped and that the structure of the labour market became more oriented towards high-skilled jobs between 2001 and 2011. Meanwhile, in the declining areas, the share of elderly increased and the share of 
university educated and high-ranking occupations decreased. This shows evidence of an increasing polarization within Lithuania.

The results presented in Table 1 also imply that the demographic and economic capacity is running low in the rapidly declining regions, which could lead to a declining quality of life. However, our survey, which was completed right after the 2011 census, showed that $96 \%$ of people living in the declining regions are actually satisfied with their standard of living (Daugirdas et al., 2013). They appreciated the natural environment, the peace and quiet, and the geographical location of their places of residence. Most problems were associated with lack of employment opportunities and cultural entertainment. Two-thirds of respondents said that the prospects for the young are poor in the declining regions, and $15 \%$ of the residents were considering leaving their current place of residence in the near future, with the main reasons being employment related. A total of $51 \%$ of the respondents who expressed their intention to leave indicated that they wanted to move to the bigger cities in Lithuania, and 39\% considered moving abroad. The results of the survey lead to the conclusion that the most sparsely populated and declining regions will continue to lose population in future. There are no indications of counterurbanization to offset population losses. A further decline of population will also affect the quality of life of those who stay as service provision will decline further. Currently, the population of the declining regions is still over 300,000 and it is a major challenge to ensure the standard of living in these regions stays sufficiently high, but at the same time is affordable. However, there is not much attention for regional development in Lithuania and there are no well-developed plans or strategies to cope with population shrinkage.

\section{Who lives in the rapidly declining regions?}

The aggregated-level data gave some first insights into the population composition of the regions of Lithuania. In this section we show the results of a series of binary logistic regression models that estimate the probability that someone lives in the rapidly declining region in 2011 compared with living in other regions of Lithuania (Table 2). These are descriptive models (as opposed to causal models) that give an indication of the role of each variable, while controlling for others. The dependent variable indicates if someone lives in a rapidly declining (losing $20 \%$ of the population or more between 2001 and 2011) region (1) or not (0). The models include a range of individual and regional-level variables. As in subsequent models, these models include only reference persons aged 18 years and older.

Model 1 includes socio-demographic characteristics. First, the model shows that the probability of living in declining regions strongly increases with age. It also shows that Lithuanians are 2.8 times more likely to live in the declining regions than other ethnic groups. This can be explained by the fact that ethnic minorities are mostly concentrated in the cities, and especially in the Vilnius city-region (Ubarevičienè, Burneika, \& van Ham, 2015). Model 1 also shows that single-person households and households with five or more members are more likely to live in declining regions than in other regions. This latter effect has been confirmed by other research (Albrecht \& Albrecht, 1996; Rogers, 1996). In addition, the model shows that with increasing levels of education, the likelihood of living in declining regions decreases rapidly: secondary educated people are 1.8 times and higher educated people are 3.6 times less likely to live in declining regions. Since women are overrepresented among the reference persons in the declining regions, the interpretation of the gender differences in the models would be biased, and only serves as a control variable.

In model 2 we included employment status variables. The results show that those with a job in the primary sector had the highest odds of living in rapidly declining regions, and those working in the service sector and students had the lowest odds. This is not surprising since the majority of the declining regions are rural areas, thus agriculture plays an important role there. 


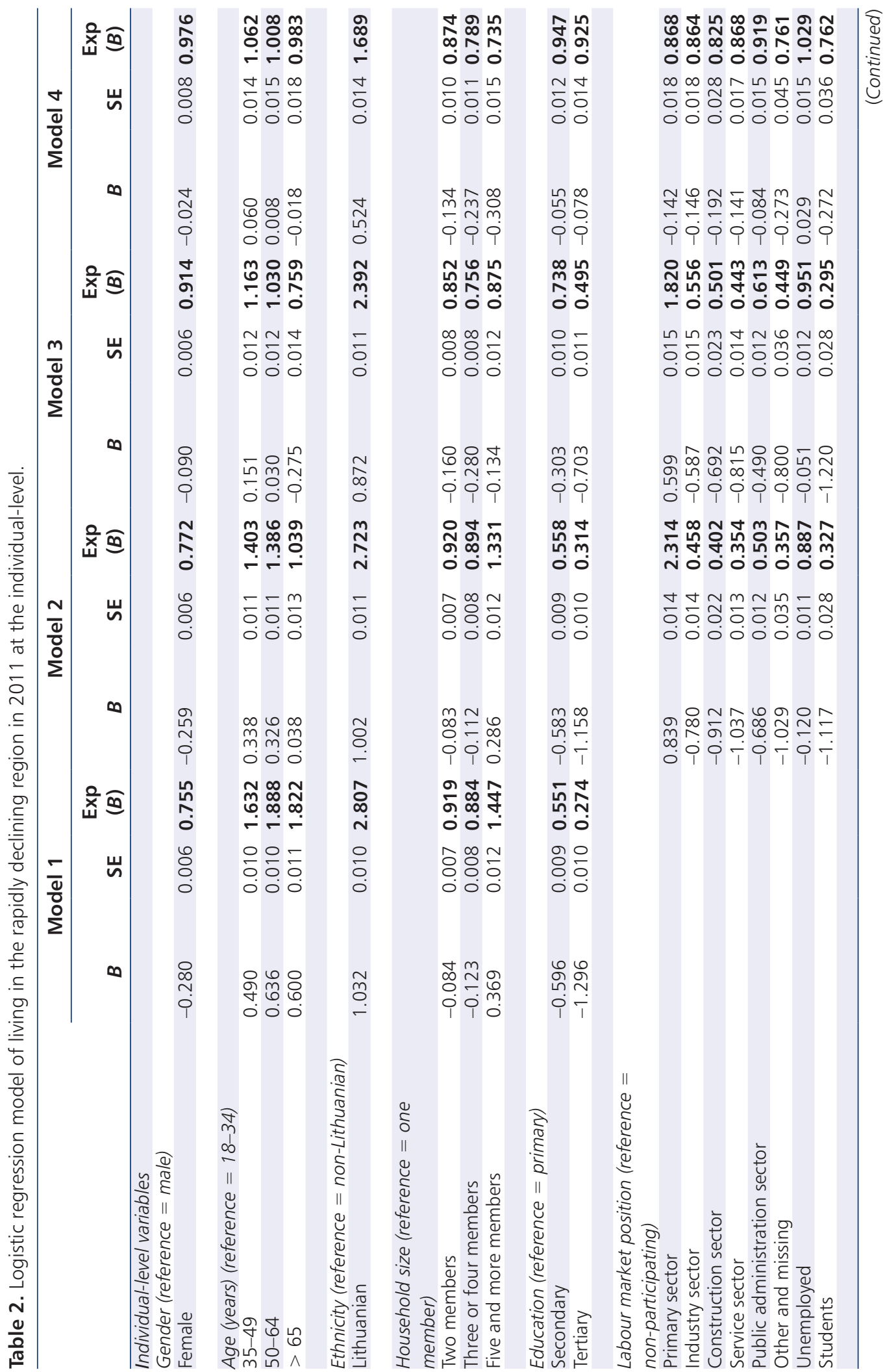




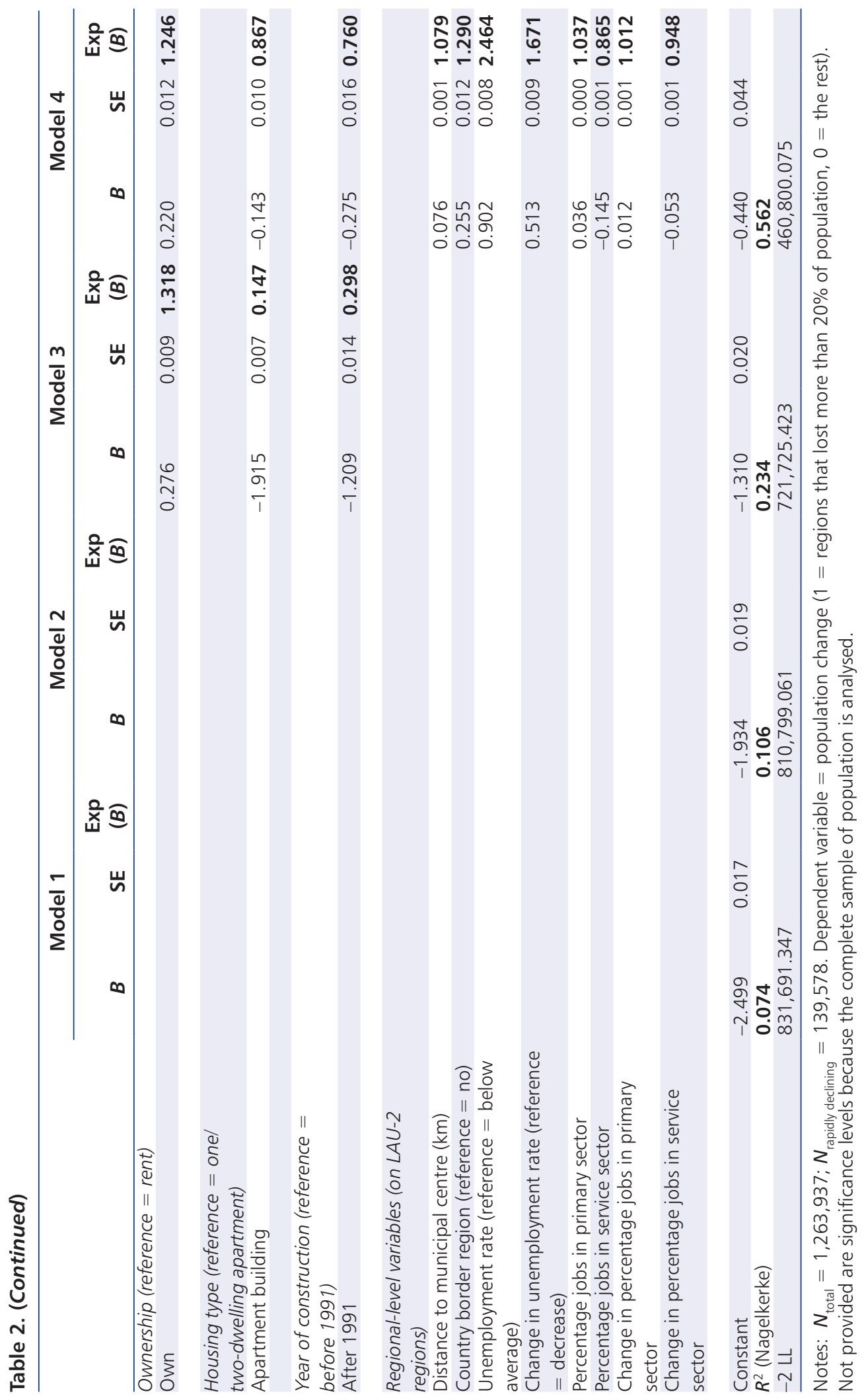


It is interesting that unemployed residents, compared with those non-participating in the labour market, were less likely to live in the declining regions. We found an opposite relationship for the rest of the country. This could be associated with the higher share of pensioners in shrinking regions, which fall within the category of non-participating. The results also showed that those having low-skilled jobs had the highest odds of living in declining regions and those having highskilled jobs had the lowest odds (not included into the models due to overlap with the variables education and labour market position). Including labour market position in model 2 also affected the effects of age compared with model 1. After controlling for employment status, the effect of the age composition diminished, especially for the oldest age group. This suggests that part of the original age effect on living in a declining area is actually an employment status effect. Meanwhile the effect of other socio-demographic characteristics hardly changed compared with model 1.

In model 3 we added housing characteristics. The results show that there is a positive effect of homeownership on the probability of living in the declining region, while the effect of living in an apartment building or more recently built dwelling was negative. The latter results are not surprising and they coincide with the descriptive data in Table 1. The effects of age and household size have nearly turned over once we controlled for housing characteristics. It can be explained by the high share of owner-occupied single-family houses. Including housing characteristics in model 3 reduced some of the effects of the other variables compared with model 2, but it increased the fit of the model considerably with a Nagelkerke pseudo- $R^{2}$ of 0.234 in model 3 .

Several regional-level variables were added in model 4 to estimate the relationship between regional characteristics and the probability to live in a rapidly declining region. The results show that people living further away from regional centres are more likely to live in a declining region, although this effect is small when we control for other characteristics. People who lived in border regions also showed a higher propensity to live in declining regions (no significant differences were found between European Union and non-European Union borders). The results also show a correlation between living in a region with a high unemployment rate (compared with country averages between 2001 and 2011) and living in one of the rapidly declining regions. Also an increasing unemployment rate (between 2001 and 2011) was associated with living in a declining region. The results also show that living in a region with a high share of jobs in the primary sector and a low share of jobs in the service sector, and living in a region with an increase in the primary sector and a drop in the service sector jobs, is associated with living in a rapidly declining region. It is noteworthy that after controlling for regional-level variables in model 4 , the differences between the categories of variables on the individual-level, such as education and labour market position, reduced. This suggests that regional-level characteristics jointly explain the essence of declining regions; high and increasing unemployment, and a low percentage of service jobs. The fit of the final model improved considerably with a Nagelkerke pseudo- $R^{2}$ of 0.562

\section{WHO LEAVES THE DECLINING REGIONS AND WHERE DO PEOPLE GO?}

Next we model leaving rapidly declining areas using multinomial logistic regression (Table 3). We distinguished between three categories of people: (1) reference category - persons who did not move from the rapidly declining regions ${ }^{6}$; (2) persons who moved into population-'winning' regions; and (3) persons who moved into population-'losing' regions. The average change in population between 2001 and 2011 at the LAU-2 level was -14.1\%, so we defined 'winning' regions as those that lost less than the average, and 'losing' if they lost more than the average. In total, there were 1605 reference persons who left declining regions between 2010 and 2011. To our surprise, 990 persons moved into 'loosing' regions and 615 moved into 'winning' regions. Like in the previous model, this model includes individual and regional-level variables.

The distribution of migrants according to population change in the destination regions is shown in Figure 2. Most of the people moved to regions that lost between $10 \%$ and $20 \%$ of 


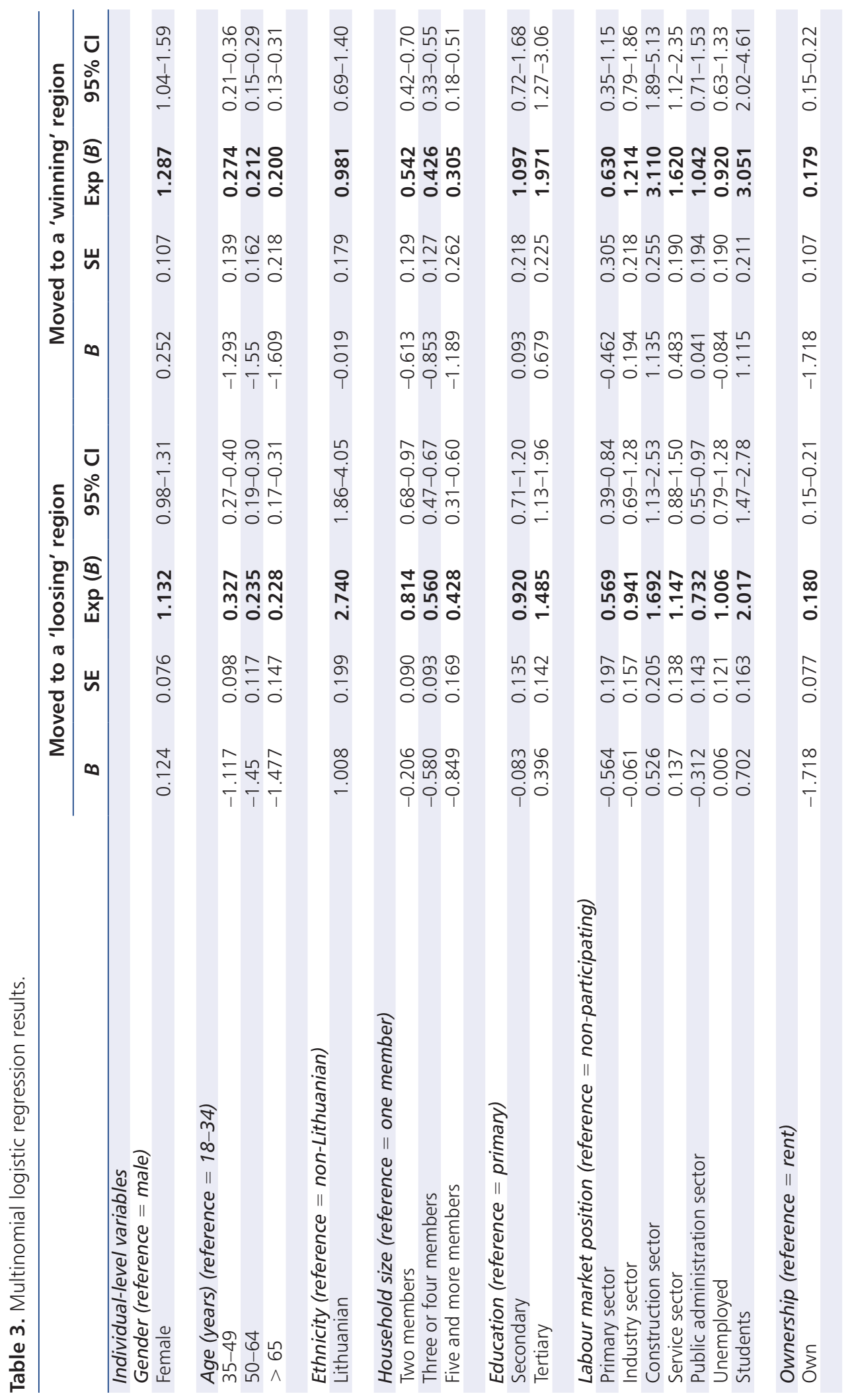




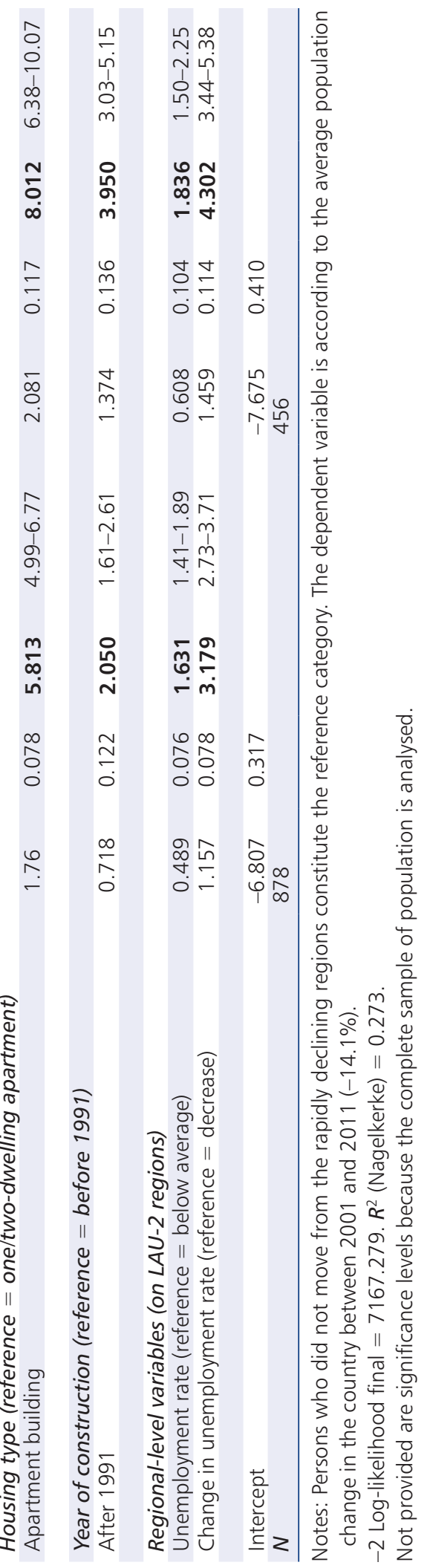




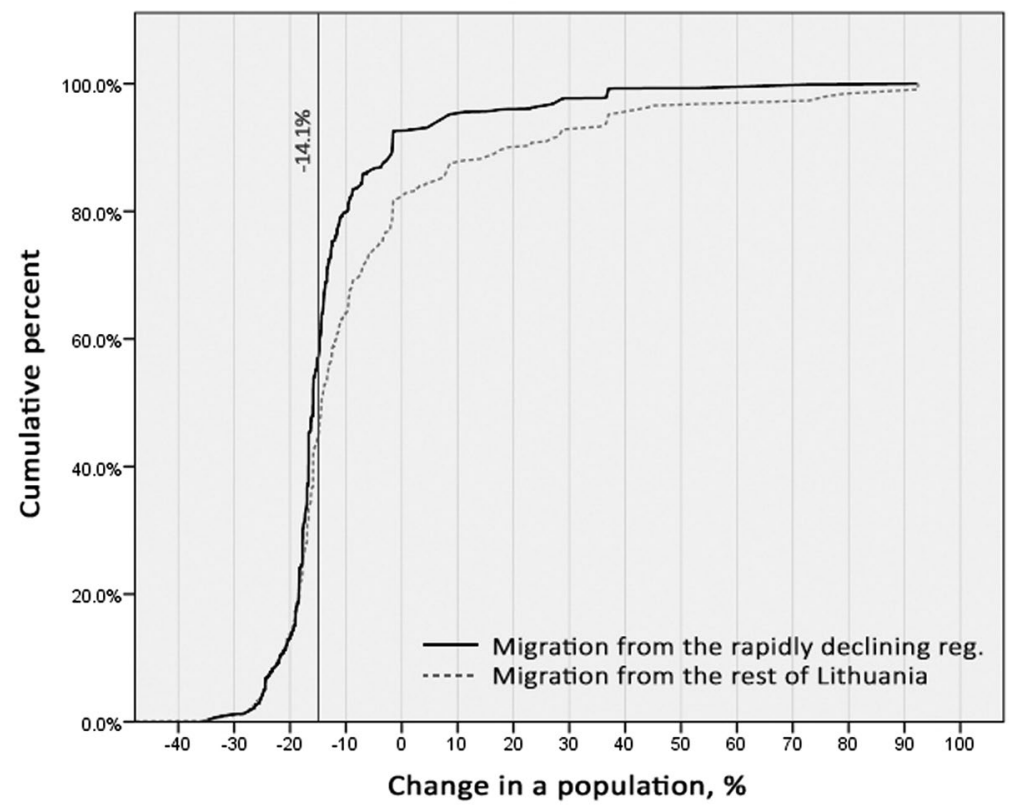

Figure 2. Distribution of migrants according to the population change in the region of destination. Source: Based on the 2011 Lithuanian census.

their population. It is interesting that migrants who moved from the rest of the country showed a similar pattern, although the curve is more to the left. It means that relatively more people moved into 'winning' regions, but the majority of residents moved into the areas that have negative population change. This spatial pattern of internal migration might be a result of the global financial crisis, since studies in Lithuania as well in other post-socialist countries have shown that the general long-term pattern of internal migration in the last two decades leads to concentration (metropolization) and peripheralization (Borén \& Gentile, 2007; Ehrlich et al., 2012; Lange, 2015). Moreover, according to census data, the number of internal migrants is very small in Lithuania, which might also be caused by the global financial crisis. Another reason might be the high homeownership rate: $83.2 \%$ of the reference persons in Lithuania and $86.1 \%$ in the rapidly declining regions lived in their own dwellings in 2011. In addition, people do not always report the change of their residence (see also Sjöberg \& Tammaru, 1999). Since the registration of the residence is voluntary and the place of residence is not directly linked with other institutions (e.g., healthcare), not updating your address does not have any legal consequences.

The results of the multinomial model in Table 3 show that the probability of migration out of rapidly declining regions decreases with age, where people aged between 18 and 34 years have much higher probabilities of leaving the rapidly declining regions than other age groups. This is in line with the results of the above-mentioned survey. Although the general trend is very similar between the two directions of migration, those who move to 'winning' regions are relatively younger. The model also shows that in general Lithuanians were more likely to move than others, but when we take into account the direction of migration, Lithuanians were more likely to have moved into 'losing' regions while there are no differences between ethnic groups with regard to moving into 'winning' regions.

When interpreting the subsequent results we have to keep in mind that for the time-varying variables (household size, education, position in the labour market, housing) we only know 
information for 2011 - after migration. This is a consequence of the use of individual-level census data. The model shows that there is a direct linear relationship between household size and migration: individuals who now (in 2011) live in smaller households were more likely to move out and those living in the large families where more likely to stay in the declining regions. This finding can be explained by family ties and related commitments (Feijten \& van Ham, 2007; Wagner \& Mulder, 2015). As in the case of age, the relationship between household size and migration is more explicit for individuals moving into 'winning' regions. Moreover, the higher the level of education a person has, the more likely that they have moved from a rapidly declining region. It is especially having a tertiary education that leads to a higher probability of moving into 'winning' regions.

People who now (in 2011) work in the primary sector were the least likely to move to both 'losing' and 'winning' regions. On the contrary, those who are now working in construction and services were more likely to leave declining regions and move to 'winning' regions. Moreover, those who work in public administration were less likely to move to 'losing' regions and those who work in industry were more likely to move to 'winning' regions. The results show that the effect of unemployment was small, although people who were unemployed in 2011 were less likely to have moved to 'winning' regions. These are valuable results, taking into account that many studies do not find a clear relationship between unemployment rates and out-migration. The model also shows that the probability of migration was higher if the person was a student in 2011 (we do not know if he/she was a student before migration, however, universities are concentrated in the biggest cities). The results also showed (data not shown) that people who now have high-ranking positions in the labour market were more likely to migrate, especially to the 'winning' regions. It means that skilled people benefit the most from migration, which is consistent with what was found in the literature review.

We have also controlled for housing characteristics. The results show that at the time of the census (2011), people who rent a house were most likely to have moved and those who are still in the declining regions were most likely to own (however, we do not know the ownership status before the move). Individuals who now live in apartment buildings as well as in the more recently built dwellings were more likely to have left, and this probability is higher for those who moved into the 'winning regions'. In other words, after migration from shrinking regions, most of the people do not own a house and often live in apartment buildings and more recently built dwellings.

Lastly, we controlled for (changes in) the unemployment rate of the origin region, which should reveal what the role is played by the regional context on the probability of leaving the shrinking regions and the destination of migration. An important finding is that the probability of migration increases with higher unemployment rates in regions of origin and this probability is even higher if the region experienced an increase in unemployment rate over the last decade. Although it means that higher unemployment rates increase the probability of leaving declining regions, those who were unemployed in 2011 were less likely to move to 'winning' regions, which were losing jobs at the time of the census. This is similar to what Tervo (2000) found in the case of Finland. We did not find effects of distance to the bigger cities or effects of the labour market structure in the region of origin on migration behaviour. In addition, the results showed (data not shown) that the effect of migration distance is small when moving to 'losing' or 'winning' region, but people tend to migrate over longer distances when they move to the major cities (especially to Vilnius), and the shortest distances when the destination is a rural area.

To summarize, the multinomial models shows that younger, better educated Lithuanians and singles were most likely to move out from rapidly declining regions. Therefore, we can state that migration flows from the declining regions which are highly selective, with relatively more 'successful' people showing a higher probability to move out. A high unemployment rate is also an important factor related to the decisions to leave rapidly declining regions. Moreover, migrants have different propensities to move into the 'losing' and 'winning' regions. Although the contrast 
is less pronounced than we could have been expecting, we found that relatively younger and highly educated people and those who live in smaller households are more inclined to move to the 'winning' regions. We did not find that those who are unemployed, uneducated and experiencing the worst living conditions were likely to move out from declining regions. This means that those who should have the greatest motivation to leave remain in the declining regions, thus reducing the attractiveness of such regions and increasing the burden on social support structures. Meanwhile, the out-migration of the younger and better educated population decreases the jobs supply and entrepreneurial capacities of declining regions, which already suffer from lack of labour supply and human capital.

Interestingly, the data also showed a group (11\% of those who moved) who moved from one rapidly declining region to another. This group of movers deserves some specific attention as they moved in the opposite direction of what economic theory would predict. We ran some additional regression models (data not shown) to examine their individual characteristics and found that compared with other movers, those who move to other declining areas are more likely to be middle aged, non-Lithuanian, living in large households, holding primary education only and unemployed. This illustrates that declining areas are hit two ways as they both loose young educated people and they receive older, worse educated and unemployed migrants.

\section{CONCLUSIONS AND DISCUSSION}

The paper explored recent processes of socio-spatial change and the role of selective migration in Lithuania. The main focus is on understanding who lives in the most rapidly declining regions and who is most likely to leave these regions. The study contributes to the existing literature by integrating population decline, migration and socio-spatial polarization, which are particularly common in post-socialist CEE countries. Although many studies emphasize increasing sociospatial polarization in $\mathrm{CEE}$ countries, little is known about the composition of internal migration flows, which is the main reason for the aforementioned emergence of regional differences. In this paper we provide solid empirical results on how these differences appear due to selective migration processes. It is also the first study to use individual-level Lithuanian census data to analyse migration, while very few studies have been done in other CEE countries, making this study of wider interest. On the other hand, the case of Lithuania is of special interest due to the history of the development of its settlement structure. It was established during the Soviet period, and the planning policy has been focused on decentralization and sought to limit the growth of the major cities. Moreover, rural-urban migration, which has long been the prevailing direction of migration in many countries, was restricted in Lithuania until the early 1990s. Therefore, we believe that the contemporary migration flows and population redistribution partially compensate for the previous restrictions on residential mobility.

Our analysis showed that older, less educated people, those working in the primary sector, and those who are unemployed, or not participating in the labour market, are the most likely to live in the most declining areas. Meanwhile, younger and single individuals with higher levels of education and better positions in the labour market are the most likely to leave depopulating areas. We also found evidence of migration selectivity by migration destination: relatively younger and higher educated individuals and those who live in smaller households are more inclined to move into 'winning' regions than to the 'losing' ones. The probability to move out increases with higher rates of unemployment in the region of origin. Although we do not know whether those who moved out were unemployed before migration, they were less likely to be unemployed after they had moved. These are important findings, since many studies do not find clear links between migration and unemployment. We also found that distance to the major cities does not have an impact on migration behaviour, though the more declining regions are the more peripheral ones. This could be related to the polycentric urban system of Lithuania. It could also mean that anyone 
who has the potential to leave has already left and the population is decreasing due to negative natural change. But it could also be the effect of the global financial crisis, which temporarily affected the spatial pattern of internal migrations. All our findings suggest that human, social and economic capital is running low in the rapidly declining regions. Moreover, the out-migration of the most 'successful' people and increasing concentration of the less 'successful' increases the gap of socio-demographic and economic differences between the rapidly declining regions and the rest of the country and leads to a spatially unbalanced development.

Uneven spatial development is a central feature of capitalist development and therefore it is typical of many countries. However, in Lithuania it is accompanied by extreme rates of population decline, thus the consequences can be expected to be profound. Despite that, there is not much attention for regional development in Lithuania and there is no policy dealing with declining regions. We could only speculate and try to guess how the declining regions of Lithuania will develop further if no action is taken. One of the most likely scenarios is that population decline will continue. The recovery of the population is only possible in a limited number of regions that can find niche markets (e.g., recreation or retirement). In contrast to popular belief, we believe that the shrinkage of these regions in Lithuania is inevitable and that out-migration gives better education and career opportunities for migrants, especially for those whose qualification can hardly be used in the shrinking agricultural labour market. It is probably not possible or even desirable to prevent further out-migration, but it is important to ensure the standard of living for those who are left behind in the declining regions. The experiences of other countries have shown that the best strategy to cope with shrinkage is through the encouragement of local incentives and citizen participation. Currently it is hardly practised in Lithuania, but the role of local communities is slowly increasing as a result of European Union support. The establishment of local self-governance might help to manage the structural processes of shrinkage.

Although our study has shortcomings, mainly related to data constraints, it is an important step on the path to a better understanding of internal migration and depopulation processes in post-socialist countries. Future empirical work should focus on selective migration by destination in order to get a better insight into the process of socio-spatial polarization. Also qualitative studies should be done in order to investigate further the living conditions and needs of the population in declining regions.

\section{FUNDING}

This work was supported by the Marie Curie programme under the European Union's Seventh Framework Programme (FP/2007-2013)/Career Integration Grant [grant number PCIG10-GA-2011-303728] (CIG Grant NBHCHOICE, Neighbourhood choice, neighbourhood sorting, and neighbourhood effects).

\section{ORCID}

Rüta Ubarevičiene (iD) http://orcid.org/0000-0002-5894-7120

Maarten van Ham (D) http://orcid.org/0000-0002-2106-0702

\section{NOTES}

1. The term 'Central and Eastern Europe (CEE)' is used here for countries that were part of the Soviet communist block from 1945/50 to 1989/91, and which now are European Union member states: Croatia, the Czech Republic, Bulgaria, Estonia, Hungary, Latvia, Lithuania, Poland, Slovakia, Slovenia, Romania and East Germany. 
2. In this paper, sometimes when using terms 'declining' or 'shrinking' we refer to 'rapidly declining regions'.

3. The decades $1945 / 50$ to $1989 / 91$ (the period of socialism lasted differently in different CEE countries).

4. There were 3342 reference persons younger than 18 years in Lithuania; they were excluded from the analysis.

5. There are three MAs in Lithuania, which contain cities and their suburban areas: Vilnius $(635,480)$, Kaunas $(392,313)$ and Klaipeda $(210,635)$ (based on the 2011 Lithuanian census).

6. Due to data limitations discussed in the data and methods section, this category also includes intra-urban or intra-rural migrants.

\section{REFERENCES}

Albrecht, E., \& Albrecht, S. L. (1996). Family structure among urban, rural and farm populations:

Classic sociological theory revisited. Rural Sociology, 61, 446-463. Retrieved from http://doi.wiley. com/10.1111/j.1549-0831.1996.tb00628.x

Ambinakudige, S., \& Parisi, D. (2015). A spatiotemporal analysis of inter-county migration patterns in the United States. Applied Spatial Analysis and Policy, 1-17. Retrieved from http://link.springer.com/10.1007/ s12061-015-9171-1

Anniste, K., Tammaru, T., Pungas, E., \& Paas, T. (2012). Emigration after EU enlargement: Was there a brain drain effect in the case of Estonia? University of Tartu - Faculty of Economics E Business Administration Working Paper Series, 86, 3-20.

van den Berg, L., Drewett, R., Klaassen, L., Rossi, A., \& Vijverberg, C. (1982). A study of growth and decline. Oxford: Pergamon Press.

Bertaud, A., \& Renaud, B. (1997). Socialist cities without land markets. Journal of Urban Economics, 41, 137-151. Retrieved from http://apps.webofknowledge.com/full_record.do?product=WOS\&search_ mode=Refine\&qid=7\&SID=4E1ICj4J3p571@nD@bA\&page=3\&doc=27

Biagi, B., Faggian, A., \& McCann, P. (2011). Long and short distance migration in Italy: The role of economic, social and environmental characteristics. Spatial Economic Analysis, 6, 111-131. Retrieved from http://www. tandfonline.com/doi/abs/10.1080/17421772.2010.540035

Black, R., Engbersen, G., Okólski, M., \& Pantîru, C. (2010). A continent moving west? EU enlargement and labour migration from central and Eastern Europe. Amsterdam: Amsterdam University Press.

Bonvalet, C., Carpenter, J., \& White, P. (1995). The residential mobility of ethnic minorities: A longitudinal analysis. Urban Studies, 32, 87-103. Retrieved from http://usj.sagepub.com/content/32/1/87.abstract

Borén, T., \& Gentile, M. (2007). Metropolitan Processes in Post-Communist States: An Introduction. Geografiska Annaler, Series B Human Geography, 89, 95-110.

Coulter, R., \& Scott, J. (2015). What motivates residential mobility? Re-examining self-reported reasons for desiring and making residential moves. Population, Space and Place, 21, 354-371. Retrieved from http:// dx.doi.org/10.1002/psp.1863

Daugirdas, V., Burneika, D., Kriaučiūnas, E., Ribokas, G., Stanaitis, S., \& Ubarevičienė, R. (2013). Lietuvos retai apgyventos teritorijos [Sparsely populated areas of Lithuania]. Vilnius: Lietuvos socialinių tyrimų centras.

Eberstadt, N. (1994). Demographic shocks after communism: Eastern Germany, 1989-93. Population and Development Review, 20,137-152. Retrieved from http://www.jstor.org/stable/2137633

Ehrlich, K., Kriszan, A., \& Lang, T. (2012). Urban development in Central and Eastern Europe - between peripheralization and centralization? disP-The Planning Review, 48, 77-92. Retrieved from http://www. tandfonline.com/doi/abs/10.1080/02513625.2012.721611

Elshof, H., van Wissen, L., \& Mulder, C. H. (2014). The self-reinforcing effects of population decline: An analysis of differences in moving behaviour between rural neighbourhoods with declining and stable populations. Journal of Rural Studies, 36, 285-299. Retrieved from http://www.sciencedirect.com/science/ article/pii/S0743016714001065 
Enyedi, G. (1998). Transformation in Central European postsocialist cities (G. Enyedi, Ed.). Discussion Papers, $21,5-47$.

Etzo, I. (2008). Internal migration: A review of the literature. MPRA paper, 8783, 1-28.

EUROSTAT. (2016). Migration and citizenship data. Retrieved from http://ec.europa.eu/eurostat/web/ population-demography-migration-projections/migration-and-citizenship-data/database

Feijten, P. \& van Ham, M. (2007). Residential mobility and migration of the divorced and separated. Demographic Research, 17, 623-654.

Finney, N., \& Simpson, L. (2008). Internal migration and ethnic groups: Evidence for Britain from the 2001 Census. Population, Space and Place, 14, 63-83.

Fratesi, U., \& Percoco, M. (2014). Selective migration, regional growth and convergence: Evidence from Italy. Regional Studies, 48, 1650-1668. Retrieved from http://www.tandfonline.com/doi/abs/10.1080/00343404.2 013.843162

Gentile, M., Tammaru, T., \& van Kempen, R. (2012). Heteropolitanization: Social and spatial change in Central and East European cities. Cities, 29, 291-299.

Haartsen, T., \& Venhorst, V. (2010). Planning for decline: Anticipating on population decline in the Netherlands. Tijdschrift voor economische en sociale geografie, 101, 218-227. Retrieved from http://doi.wiley. com/10.1111/j.1467-9663.2010.00597.x

Haase, A., Athanasopoulou, A., \& Rink, D. (2016). Urban shrinkage as an emerging concern for European policymaking. European Urban and Regional Studies, 23, 103-107. Retrieved from http://eur.sagepub.com/ cgi/doi/10.1177/0969776413481371

Haase, A., Bernt, M., Großmann, K., Mykhnenko, V., \& Rink, D. (2016). Varieties of shrinkage in European cities. European Urban and Regional Studies, 23, 86-102. Retrieved from http://eur.sagepub.com/cgi/ doi/10.1177/0969776413481985

Hospers, G.-J. (2012). Coping with shrinkage in Europe's cities and towns. Urban design international, 18, 78-89. Retrieved from http://www.palgrave-journals.com/doifinder/10.1057/udi.2012.29

Hudson, R. (2015). Uneven Development, Socio-Spatial Polarization and Political Responses. In T. Lang, S. Henn, W. Sgibnev, \& K. Ehrlich (Eds.), Understanding Geographies of Polarization and Peripheralization (pp. 25-39). London: Palgrave Macmillan UK. Retrieved from http://dx.doi.org/10.1057/9781137415080_2

Kährik, A., \& Tammaru, T. (2008). Population composition in new suburban settlements of the Tallinn metropolitan area. Urban Studies, 45, 1055-1078. Retrieved from < Go to ISI >:/WOS:000256195400003\n http://usj.sagepub.com/content/45/5-6/1055.full.pdf

Kok, H., \& Kovács, Z. (1999). The process of suburbanization in the agglomeration of Budapest. Netherlands Journal of Housing and the Built Environment, 14, 119-141.

Lange, T. (2015). Socio-economic and political responses to regional polarisation and socio-spatial peripheralisation in Central and Eastern Europe: A research agenda. Hungarian Geographical Bulletin, 64, 171-185. Retrieved from http://www.mtafki.hu/konyvtar/hungeobull_64_3_2_en.html

Leetmaa, K., \& Tammaru, T. (2007). Suburbanization in countries in transition: Destinations of suburbanizers in the Tallinn metropolitan area. Geografiska Annaler, Series B Human Geography, 89, 127-146.

Myrdal, G. (1957). Economic theory and underdeveloped regions. London: Duckworth.

Ní Laoire, C. (2000). Conceptualising Irish rural youth migration: A biographical approach. International Journal of Population Geography, 6, 229-243.

Niedomysl, T. (2011). How migration motives change over migration distance: Evidence on variation across socio-economic and demographic groups. Regional Studies, 45, 843-855.

Nivalainen, S. (2004). Determinants of family migration: short moves vs. long moves. Journal of Population Economics, 17, 157-175. Retrieved from http://link.springer.com/10.1007/s00148-003-0131-8

Nuissl, H., \& Rink, D. (2005). The 'production' of urban sprawl in eastern Germany as a phenomenon of postsocialist transformation. Cities, 22, 123-134.

Ouředníček, M. (2007). Differential suburban development in the Prague urban region. Geografiska Annaler, Series B: Human Geography, 89, 111-126. 
Panagopoulos, T., \& Barreira, A. P. (2012). Shrinkage perceptions and smart growth strategies for the municipalities of Portugal. Built Environment, 38, 276-292.

Pociūtè-Sereikienè, G., Kriaučiūnas, E., \& Ubarevičienė, R. (2014). Peripheralisation trends in rural territories : The case of Lithuania. Studies in Agricultural Economics, 116, 122-130.

Reher, D. S. (2004). The demographic transition revisited as a global process. Population, Space and Place, 10, 19-41. Retrieved from http://doi.wiley.com/10.1002/psp.313

Rogers, C. C. (1996). Age and family structure, by race/ethnicity and place of residence, in: L.L.Swanson (Ed.), Racial/ethnic minorities in rural areas: Progress and stagnation, pp. 42-53. Washington, D.C.: Economic Research Service.

Rychtaříková, J. (1999). Is Eastern Europe experiencing a second demographic transition? Acta Universitatis Carolinae Geographica, 34, 19-44.

Sjaastad, L. A. (1962). The costs and returns of human migration. Journal of Political Economy, 70, 80-93.

Sjöberg, Ö. (1999). Shortage, priority and urban growth: Towards a theory of urbanisation under central planning. Urban Studies, 36, 2217-2236. Retrieved from http://usj.sagepub.com/content/36/13/2217.short

Sjöberg, Ö., \& Tammaru, T. (1999). Transitional statistics: Internal migration and urban growth in post-soviet Estonia. Europe-Asia Studies, 51, 821-842. Retrieved from http://www.ncbi.nlm.nih.gov/pubmed/12296066 Smith, A., \& Timar, J. (2010). Uneven transformations: Space, economy and society 20 years after the collapse of state socialism. European Urban and Regional Studies, 17, 115-125. Retrieved from http://eur.sagepub. com/cgi/doi/10.1177/0969776409358245

Sobotka, T., Zeman, K., \& Kantorová, V. (2003). Demographic shifts in the Czech Republic after 1989: A second demographic transition view. European Journal of Population/Revue europenne de Demographie, 19, 249-277.

Sousa, S., \& Pinho, P. (2015). Planning for shrinkage: Paradox or Paradigm. European Planning Studies, 23, 12-32. Retrieved from http://www.tandfonline.com/doi/abs/10.1080/09654313.2013.820082

Statistics Lithuania (2012). Lithuanian 2011 Population Census in Brief. Vilnius: Statistics Lithuania.

Statistics Lithuania. (2017). Database. Retrieved from http://osp.stat.gov.lt/web/guest/statistiniu-rodikliuanalize?epoch $=\mathrm{ML}$

Steinführer, A., \& Haase, A. (2007). Demographic change as a future challenge for cities in east central Europe. Geografiska Annaler, Series B Human Geography, 89, 183-195.

Stockdale, A. (2004). Rural out-migration: Community consequences and individual migrant experiences. Sociologia Ruralis, 44, 167-194.

Tammaru, T. (2001). Suburban growth and suburbanisation under central planning: The case of soviet Estonia. Urban Studies, 38, 1341-1357. Retrieved from < Go to ISI >://000169407400008

Tammaru, T., van Ham, M., Leetmaa, K., Kährik, A., \& Kamenik, K. (2013). The ethnic dimensions of suburbanisation in Estonia. Journal of Ethnic and Migration Studies, 39, 845-862.

Tervo, H. (2000). Migration and labour market adjustment: Empirical evidence from Finland 1985-90. International Review of Applied Economics, 14, 343-360.

Thaut, L. (2009). EU integration \& emigration consequences: The case of Lithuania. International Migration, $47,192-233$.

The Economist. (2017). Eastern Europe's workers are emigrating, but its pensioners are staying. Retrieved from http://www.economist.com/news/europe/21714999-eus-newest-members-face-economic-decline-unlessthey-woo-back-workers-or-recruit-immigrants

Ubarevičienè, R. (2016). Lietuvos gyventojų vidaus migracijų teritoriniai ypatumai 21 a [Territorial features of internal migration of Lithuanian population in the 21st century]. Lietuvos socialine raida: teritorinis aspektas, $5,9-24$.

Ubarevičiené, R., Burneika, D., \& van Ham, M. (2015). Ethno-political effects of suburbanization in the Vilnius urban region: An analysis of voting behavior. Journal of Baltic Studies, 46, 217-242. Retrieved from http://www.tandfonline.com/doi/full/10.1080/01629778.2015.1027935 
Ubarevičiené, R., van Ham, M., \& Burneika, D. (2016). Shrinking regions in a shrinking country: The geography of population decline in Lithuania 2001-2011. Urban Studies Research,1-18. Retrieved from http://www.hindawi.com/journals/usr/2016/5395379/

United Nations. (2015). World Population Prospects: The 2015 Revision. United Nations, Department of Economic and Social Affairs, Population Division.

Valatka, V., Burneika, D., \& Ubarevičienė, R. (2016). Large social inequalities and low levels of socio-economic segregation in Vilnius. In T. Tammaru, S. Marcińczak, M. van Ham, \& S. Musterd (Eds.), Socio-economic segregation in European Capital cities: East meets West (pp. 313-332). London and New York: Routledge.

Vanagas, J., Krišjane, Z., Noorkoiv, R., \& Staniūnas, E. (2002). Planning urban systems in Soviet times and in the era of transition: The case of Estonia. Latvia and Lithuania. Geographia Polonica, 75, 75-100.

Wagner, M., \& Mulder, C. H. (2015). Spatial mobility, family dynamics, and housing transitions. KZfSS Kölner Zeitschrift für Soziologie und Sozialpsychologie, 67,111-135. Retrieved from http://link.springer.com/10.1007/ s11577-015-0327-4 